\title{
Research Area, Work Experience And Parents' Completed Higher Education Within Scientists' Intellectual Leadership in Higher Education: Which Roles Matter?
}

\author{
Vilma Zydziunaite, Professor, PhD \\ Social sciences, Education \& Health sciences, Nursing, MA Education, MA \\ Nursing, BA Nursing, RN \\ Vytautas Magnus University, Kaunas, Lithuania
}

doi: 10.19044/esj.2016.v12n25p9 URL:http://dx.doi.org/10.19044/esj.2016.v12n25p9

\begin{abstract}
Scientists as intellectual leaders are seen through their expertise and the scope of knowledge. The research issue in this pilot study was related to scientists ${ }^{6}$ working in higher education schools and focused on intellectual leadership, which consists of different roles.

The participants of the pilot study were researchers with acquired PhD. Data collection were accomplished by implementing the questioning survey from 2015-06-02 to 2015-06-30. In total 138 respondents filled in the instrument, but for data analysis were suitable 131 instrument. For data analysis were applied descriptive statistics, correlation analysis (Spearman), ANOVA, and Cronbach's alpha was calculated.

Findings showed that the roles of the advocate and critic for researchers from social sciences were more worth than for researchers from other research areas. The lowest assessments were related to the role of the mentor nevertheless of the scientist's research area. Results revealed that more experienced scientists in higher education area more value the roles of academic citizen and public intellectual. The roles of ambassador, critic, advocate were assessed more positively by scientists one of whose parents was educated in higher education school.

Intellectual leadership of a scientist in higher education is about everyday learning. The particular roles of a scientist are not in position of status quo. The core messages from this pilot study are the following: scientists from social research area see more complex their roles in higher education school; work experience of the scientist in higher education and the completed higher education of scientist's parents matter.
\end{abstract}

Keywords: Higher education, intellectual leadership, piloting, scientist, role 


\section{Introduction}

When the higher education became the object of mass consumption, the universities developed with amounts of students in it. At the same time significantly increased the number of universities in order to meet the growing scale of demands. For this reason increased the popularity of academic profession (researcher's or scentist's). Such situation in higher education development gradually weakened the prestige of the profession, social status and rewards for academic work (Gornitzka et al., 2005).

Changes in the activities of the scientist are influenced by managerialism, which is the characteristic of the contemporary university. It means that higher education processes at universities are regulated according to managerial principles. It changed essentially the academic work and the identity of the scientist in society and in higher education school (Harpur, 2010).

Today the professional and academic identity of the scientist may be seen through the role of a scientist-administrator. Within this role the key values are related to the managerial discourse. The other role is related to the scientist who is administrated by the formal institutional managerial structure. In such case the values of the scientist does not overlap with the managerialism (Jain et al., 2009). Carmeli \& Halevi (2009) relate the change in scientist's identity with the mission, strategies of marketing and long-term goals of the higher education institution. These mentioned components are provided by leaders from higher education institution, but not by scientists. In such case scientists are followers, performers, creators, who are able to adopt their intellectual skills to higher education institutions' aims and objectives.

Scientists relate the change in their activities with the work intensity, work overloads, continuous stress because of time limits. It affects not only the quality of the scientific work, but also the physical and psychological health of the scientist (Albert et al. 2000). Entrepreneurship is the other characteristic of contemporary universities, which makes the significant impact on the work of scientists. Scientists accentuate that the university's attention to entrepreneurship and profitable activities cause the value conflict for them, because they the essential aim and purpose see in education, discoveries and creativity (Harpur, 2010).

Scientists as intellectual leaders are seen through their expertise and the scope of knowledge. The roles of the scientist in higher education school include a number of activities. These activities might be unsteady and constantly improved in order to ensure the continuity of teaching and research (Brinley, 2012). A scientist's role in a contemporary higher education incorporates intellectual leadership with management occurring almost incidentally and depending on the personal qualities of the scientist and administrative staff (Murphy \& Curtis, 2013). 
The research issue in this pilot study was related to scientists' ${ }^{6}$ working in higher education schools and focused on intellectual leadership, which consists of variety of roles. It is worth to discover how scientists identify themselves within their roles in higher education. In this piloting study findings answered the following research question: "What are the relationships between the scientists' roles in higher education and their research area, work experience and their parents' completed higher education?" The aim of the pilot study was to reveal the roles performed by scientists through implementing the intellectual leadership in higher education.

\section{Framework of intellectual leadership in higher education: roles and its characteristics}

Macfarlane $(2011,2012)$ describes the scientist's roles in regard to his / her intellectual leadership in higher education. Roles of the scientist by implementing the intellectual leadership in higher education are the following: ambassador, critic, advocate, mentor, guardian, enabler, knowledge producer, academic citizen, boundary transgressor, and public intellectual (see Table 1).

Table 1

Characteristics of scientist's roles by implementing the intellectual leadership in higher education (according to Macfarlane, 2011, 2012)

\begin{tabular}{|c|c|}
\hline Role & Characteristics \\
\hline Ambassador & $\begin{array}{c}\text { Representing the higher education institution in local, national } \\
\text { and international levels. }\end{array}$ \\
\hline Critic & $\begin{array}{l}\text { Providing opinions, expertises regarding scientific and non- } \\
\text { scientific questions within the research discipline. }\end{array}$ \\
\hline Advocate & $\begin{array}{l}\text { Supporting and guiding the less experienced colleagues regarding } \\
\text { transferring their knowledge and intellectual skills to individuals } \\
\text { and society in local, national and international levels by applying } \\
\text { the particular theoretical frameworks. }\end{array}$ \\
\hline Mentor & $\begin{array}{l}\text { Guiding and facilitating the research activities, collaborating with } \\
\text { less experienced colleagues, and young researchers. }\end{array}$ \\
\hline Guardian & $\begin{array}{l}\text { Representing the academic values and standards and contributing } \\
\text { to the development of research field in new directions. }\end{array}$ \\
\hline Enabler & $\begin{array}{l}\text { Supporting young researchers and junior colleagues and their } \\
\text { research initiatives by coordinating and leading project teams to } \\
\text { obtain research funds. }\end{array}$ \\
\hline Knowledge producer & $\begin{array}{l}\text { Having an impact on theory and practices through application of } \\
\text { new theories, models, research evidences, and reflective research } \\
\text { practices. }\end{array}$ \\
\hline Academic citizen & $\begin{array}{c}\text { Applying own knowledge and intellectual skills for the benefit of } \\
\text { development of public awareness. }\end{array}$ \\
\hline $\begin{array}{l}\text { Boundary } \\
\text { transgressor }\end{array}$ & $\begin{array}{l}\text { Creating the relationships and revealing overlaps between } \\
\text { theories, practices, models, frameworks, and disciplines. }\end{array}$ \\
\hline
\end{tabular}


Seeking to influence the public debate on political, research, social, moral, law, economic and other issues through

Public intellectual participating in social, political, and scientific debates in variety of forms.

\section{Methodology Design}

The purpose of the pilot study is dual: on the one hand it is small-scale preparatory study; on the other hand it is testing and validating the research instrument (van Teijlingen \& Hundley, 2001; Fowler, 2014). The pilot study was a quantitative fixed design empirical research, carried out by a quantitative research strategy by implementing questioning survey (Zydziunaite, 2007) with application of closed-ended questionnaire.

\section{Sampling and data collection}

Determination of a sample size in a pilot study is not unambiguous. Depending on the purpose of the investigation (verification of research procedure and validation of the instrument), the number of research participants' groups (one or several), the chosen level of confidence and power, the size of the pilot sample may differ (Julious, 2005; Connelly, 2008). In this pilot study key objectives were to verify the performance of the same research procedure and to check the constructed empirical research instrument. The key feature in selection of research participants was the requirement to have the formal qualification - the acquired $\mathrm{PhD}$ degree.

Here is not the uniquely identified size of the pilot sample. It is recommended that a pilot study sample size should not be less than 80 respondents by taking in account the following aspects (Hertzog, 2008): i) sample size: according to Review on Situation of Research and Study in Lithuania (2016) in Lithuania in full or part-time, worked as researchers / scientists approximately, 18083 representatives of Lithuania's population and not all of them already had a $\mathrm{PhD}$; ii) verification of the instrument's validity: calculating Cronbach's alpha from acquired data; iii) results that are calculated in relation to the sample: there were calculated the correlation analysis and means by applying the probability of 1 st level error occurrence $\alpha=0,05$; iv) number of groups: results were calculated within one group.

The participants of the general population were respondents with acquired $\mathrm{PhD}$. In total were properly filled in 131 instrument. Among respondents 69 percent were women, and 31 percent - men. The acquisition time of doctoral degree (PhD) among respondents was from 1972 to 2015 years. 13 percents (17 respondents) of research participants defended their dissertations before 1990 year. The biggest number (10 respondents) of research participants defended dissertations in 2005 year. 93 percents of respondents (122 persons) defended $\mathrm{PhD}$ dissertations in Lithuania, 4 persons in Russia, 3 respondents in United States of America, 1 in Finland and 1 in 
Netherlands. The biggest part -57 percents ( 75 respondents) - defended their $\mathrm{PhD}$ 's in social sciences (see Table 2).

Table 2

Research areas of defended dissertations among respondents

\begin{tabular}{ccc}
\hline Research area & Quantity & Percentage \\
Social sciences & 75 & 57 \\
Humanities & 16 & 12 \\
Exact sciences & 8 & 6 \\
Health sciences & 12 & 9 \\
Technological sciences & 9 & 7 \\
Natural sciences & 11 & 9 \\
In total & 131 & 100 \\
\hline
\end{tabular}

Most part of respondents within a pilot sample had academic exprience of more than 5 years in higher education school (see Table 3 ).

Table 3

Work experience of respondents in higher education school

\begin{tabular}{ccc}
\hline Work experience & Quantity & Percentage \\
Up to 1 year & 8 & 6 \\
1-5 years & 10 & 8 \\
6-10 years & 29 & 22 \\
11-15 years & 25 & 19 \\
16-20 years & 28 & 21 \\
Over 20 years & 31 & 24 \\
In total & 131 & 100 \\
\hline
\end{tabular}

The smallest part of the sample consisted of up to 30 years old persons and researchers over 65 years old. The biggest part of the pilot sample consisted of 41-45 years old respondents (see Table 4).

Table 4

Age of respondents

\begin{tabular}{ccc}
\hline Age & Quantity & Percentage \\
25-30 years old & 4 & 3 \\
31-35 years old & 18 & 14 \\
36-40 years old & 19 & 15 \\
41-45 years old & 32 & 24 \\
46-50 years old & 13 & 10 \\
$51-55$ years old & 16 & 12 \\
$56-60$ years old & 18 & 14 \\
61-65 years old & 6 & 5 \\
Over 65 years old & 5 & 4 \\
In total & 131 & 100 \\
\hline
\end{tabular}

60 respondents (46 percents) were raised in families, in which both parents were completed the higher education school (see Table 5).

Table 5

Acquired higher education of scientists' parents

Statement Quantity


I was raised in family, in which both parents

60

completed the higher education school

I was raised in family, in which one of parents completed the higher education school

Data collection in pilot study were accomplished by implementing the questioning survey with the closed-ended questionnaire. Within one month (from 2015-06-02 to 2015-06-30) 138 respondents filled in the instrument. For data analysis were suitable 131 instrument.

\section{Data analysis}

For data analysis were applied the statistical analysis methods by using MS Excel and SPSS (Statistical Package for Social Sciences, version 22). The descriptive statistics were applied to explain the collected information by calculating the values within the sample (Gay \& Airasian, 2003). Descriptive statistics provided the possibiliy to represent the collected data through percents, means, and standard deviations. Striving to assess the efficiency of statistical procedures and planning the main research study (after pilot study) was calculated the mean for every block (as derivated parameters) within the instrument, which showed the average rating regarding particular role and every respondent. The resulting value varied from 1 to 5 .

The correlation analysis were used to detect the strength of the relationship within the every block of the instrument. One block described one role. In order the statements would be related they must be interrelated. If the correlation between statements does not exist then it is important to think about rejecting the concrete statements and / or roles in main research study (after pilot study) (Zou ir kt., 2003). For calculation was applied the Spearman correlation coefficient. Correlations between blocks were calculated in order to identify, which blocks are interrelated significantly. The strong correlation between blocks means that the calculated aspects are interdependent or must be combined, because they assess the same aspect (Gay \& Airasian, 2003).

The parametric criteria (ANOVA of blocked data) were applied by seeking to compare indexes between different groups of respondents. The comparison of means together with derivated indexes was important in pilot study by striving to assess the priorities between the scientists' roles. ANOVA was applied for comparison of means between two and more groups. Mann Whitney criterion was used for comparison in two groups. The values for assessing the scientists' roles did not meet the assumptions of normality then the non-parametric Mann Whitney criterion was applied for comparisons.

In pilot study were applied Cronbach's alpha, which results showed the internal compatibility within the subscale (in this pilot study case within the block). Compatibility is sufficient if Cronbach's alpha exceeds 0.7. If Cronbach's alpha exceeds 0.9 it is important to assess the number of elements 
within the scale, i.e. to check is it not too high? (Tavakol \& Dennick, 2011). The assurance of the internal compatibility is necessary, but it is not the only condition by striving to assure the homogeneity and wholiness of dimensions within the instrument (Zou ir kt., 2003).

\section{Ethics}

In pilot study the focus were on the following principles (Hennink et al., 2011): information conveyance, free participation, avoiding the influence or effect on research participants, anonimity, and confidentality. In piloting study research participants received the cover letter, in which they were acquainted with the research aim, ethical principles and the intentions to apply the research findings for particular goals.

\section{Tool}

The original validated questionnaire (Zydziunaite et al., 2015a, b) on scientist's roles in higher education was created. The construct of the tool was based on the conception of Macfarlane $(2011,2012)$ on 'Intellectual Leadership in Higher Education'. The conceptual framework was enriched by publications of Dealtry (2001), Rowley \& Sherman (2003), Yielder \& Codling (2004), Blackmore \& Blackwell (2006), Roy et al. (2008), Tseng et al. (2010), Stevenson (2012). The questionnaire for data collection consisted of 3 parts, 15 questions and 212 statements in total. The Cronbach's values of the tool were $0.787-0.912$ (see Table 6).

Table 6

Characteristics of the pilot study instrument

\begin{tabular}{ccc}
\hline Content of parts and type of every question & $\begin{array}{c}\text { No. of } \\
\text { statements }\end{array}$ & $\begin{array}{c}\text { Cronbach's } \\
\text { alpha }\end{array}$ \\
$1^{\text {st }}$ part (academic values) & & 0.878 \\
Academic freedom (closed ended question) & 13 & 0.895 \\
Academic duty (closed ended question) & 15 & - \\
Academic values (open ended question) & - & - \\
In total (the $1^{\text {st }}$ part) & 28 & 0.877 \\
$2^{\text {nd }}$ part (roles) & & 0.857 \\
The ambassador (closed ended question) & 5 & 0.787 \\
The critic (closed ended question) & 35 & 0.804 \\
The advocate (closed ended question) & 18 & 0.841 \\
The mentor (closed ended question) & 13 & 0.912 \\
The guardian (closed ended question) & 9 & 0.861 \\
The enabler (closed ended question) & 11 & 0.842 \\
The knowledge producer (closed ended question) & 15 & 0.886 \\
The academic citizen (closed ended question) & 8 & 0.792 \\
The boundary transgressor (closed ended question) & 14 & - \\
The public intellectual (closed ended question) & 10 & \\
In total (the $2^{\text {nd }}$ part) & 138 & \\
\hline
\end{tabular}




\begin{tabular}{ccc}
\hline Research area of the discipline (multichoice & 7 & - \\
question) & 7 & - \\
Scientist's research area (multichoice question) & 6 & - \\
Research area and discipline of the defended PhD & & - \\
(multichoice question) & - & - \\
Year of PhD defence (open ended question) & - & - \\
Country of PhD defence (open ended question) & - & - \\
Country, in which the scientist works in higher & & - \\
education school (open ended question) & - & - \\
Scientist's religion (open ended question) & 6 & - \\
Work experience in higher education school & & - \\
(multichoice question) & 2 & - \\
Acquired MA degree (multichoice question) & 6 & - \\
Acquired MA degree area and discipline & & - \\
(multichoice question) & 9 & 3 \\
Age of the scientist (multichoice question) & 46 & - \\
Gender of the scientist (multichoice question) & 212 & In total (the 3rd part) \\
In total (the whole instrument) &
\end{tabular}

To measure every statement in the $2^{\text {nd }}$ part respondents were asked to use the Likert-type scale ranging from 1 (totally disagree) to 5 (totally agree). In this article are discussed results, which are related only to the $2^{\text {nd }}$ and $3^{\text {rd }}$ parts of the instrument.

\section{Results}

Findings reveal the main aspects that are related to the scientists' intellectual leadership in higher education in regard to their research area, work experience and the completed higher education of their parents.

Research area within scientists' intellectual leadership in higher education. Amount of respondents, who perform research in different research areas was diverse. The biggest part of respondents consisted of scientists who are involved into social research. Therefore a comparison was focused on measuring responses of scientists from social sciences and other sciences (see Table 7).

Table 7

Comparison of scientists' roles in higher education according to research area Mean of Role responses of scientists from Mean of responses of scientists from Mann social sciences other sciences

Whitney U p

\begin{tabular}{ccccc}
\hline Ambassador & 3.87 & 3.77 & 1838.5 & 0.371 \\
Critic & 3.58 & 3.39 & 1326 & 0.012 \\
Advocate & 3.28 & 2.21 & 1276.5 & 0.000 \\
Mentor & 3.68 & 3.59 & 1389.5 & 0.573 \\
Guardian & 3.35 & 3.25 & 1313 & 0.455 \\
Enabler & 3.60 & 3.44 & 1187 & 0.224 \\
\hline
\end{tabular}




\begin{tabular}{ccccc}
\hline Knowledgde & 3.68 & 3.57 & 1179 & 0.331 \\
producer & 3.77 & 3.57 & 1010 & 0.096 \\
Academic citizen & 3.49 & 3.32 & 1105.5 & 0.306 \\
Boundary & 3.03 & 2.83 & 993 & 0.114 \\
transgressor & & \\
Public intellectual & &
\end{tabular}

Results revealed that the most significant differences between scientists from social research and other research areas were regarding their responses on the role of the advocate. Though the role of the advocate was evaluated undermost: responses of scientists from non-social research area were very low (2.21); meanwhile, the mean of responses of representatives from social research area was higher total score (3.28) (within a five-scale). Applying non-parametric Mann-Whitney criterion for evaluation of the role of the advocate, here were fixed the statistically meaningful difference $(\mathrm{p}=0.000)$. Statistically meaningful difference also was measured by comparing the opinions of respondents regarding the role of the critic. Here the difference was not so meaningful - the mean of evaluations of scientists from social sciences was 3.58. The mean of responses of representatives from non-social sciences was $3.39(\mathrm{p}=0.012)$. Comparisons of responses of the scientists regarding other roles did not reveal the statistically significant differences. In all cases of responses regarding different roles in higher education, the scientists from social sciences provided higher assessments. The lowest assessments were related to the role of the mentor.

Work experience of scientists by implementing the intellectual leadership in higher education. Work experience of the research paticipants in higher education ranged from one to twenty or more years. Dividing the cohort of respondents into intervals of five years according the work experience in higher education and applying ANOVA, were calculated the comparisons of the statistical means (see Table 8).

Table 8

Comparison of scientists' roles according to work experience in higher education

\begin{tabular}{|c|c|c|c|c|c|c|c|c|c|}
\hline \multirow[t]{2}{*}{ Role } & \multicolumn{6}{|c|}{ Work experience in higher education } & \multicolumn{3}{|c|}{ ANOVA } \\
\hline & $\begin{array}{l}\text { Up } \\
\text { to } 1 \\
\text { year }\end{array}$ & $\begin{array}{c}1-5 \\
\text { years }\end{array}$ & $\begin{array}{c}6-10 \\
\text { years }\end{array}$ & $\begin{array}{l}11-15 \\
\text { years }\end{array}$ & $\begin{array}{l}16-20 \\
\text { years }\end{array}$ & $\begin{array}{c}\text { Over } \\
20 \\
\text { years }\end{array}$ & $\mathrm{F}$ & $\begin{array}{l}\mathrm{df}_{1} \\
\mathrm{df}_{2}\end{array}$ & $\mathrm{p}$ \\
\hline Ambassador & 3.57 & 3.90 & 3.81 & 3.76 & 3.89 & 3.95 & 0.440 & $\begin{array}{c}5 \\
92\end{array}$ & 0.894 \\
\hline Critic & 3.44 & 3.48 & 3.42 & 3.84 & 3.55 & 3.66 & 2.492 & $\begin{array}{c}5 \\
92\end{array}$ & 0.017 \\
\hline Advocate & 3.27 & 3.01 & 3.18 & 3.52 & 3.35 & 3.40 & 1.385 & $\begin{array}{c}5 \\
93\end{array}$ & 0.213 \\
\hline Mentor & 3.33 & 3.54 & 3.58 & 3.94 & 3.81 & 3.75 & 1.670 & $\begin{array}{c}5 \\
90\end{array}$ & 0.117 \\
\hline Guardian & 2.98 & 3.16 & 3.18 & 3.46 & 3.50 & 3.72 & 1.354 & 5 & 0.228 \\
\hline
\end{tabular}




\begin{tabular}{ccccccccccc}
\hline Enabler & 3.23 & 3.61 & 3.33 & 3.92 & 3.87 & 3.77 & 1.369 & 5 & 0.221 \\
$\begin{array}{c}\text { Knowledgde } \\
\text { producer }\end{array}$ & 3.51 & 3.59 & 3.47 & 3.94 & 3.79 & 3.83 & 1.001 & 5 & 0.441 \\
$\begin{array}{c}\text { Academic } \\
\text { citizen }\end{array}$ & 3.40 & 3.64 & 3.48 & 4.15 & 4.03 & 3.98 & 2.436 & 5 & 0.020 \\
$\begin{array}{c}\text { Boundary } \\
\text { transgressor } \\
\begin{array}{c}\text { Public } \\
\text { intellectual }\end{array}\end{array}$ & 3.14 & 3.45 & 3.38 & 3.68 & 3.40 & 3.55 & 0.854 & 5 & 0.558 \\
\hline
\end{tabular}

ANOVA results highlighted that statistically meaningful differences were identified by assessing the roles of critic, academic citizen and public intellectual. The role of the critic was recognized by scientists who had the work experience in higher education from 11 to 15 years. Their assessments were of highest ratings (3.84). Assessments in other groups according to work experience intervals were lower $(\mathrm{p}=0.017)$. Scientists who had the work experience in higher education from 10 years and more, higher assessed the role of the academic citizen. While scientists with a lower work experience assessed their roles in higher education with lower values $(\mathrm{p}=0.020)$. Scientists who had experience up to 1 year or from 6 to 10 years assessed the role of the public intellectual with lowest values. But the mean of assessments by scientists with more experience in higher education was higher, then the difference between these groups was statistically meaningful $(\mathrm{p}=0.015)$.

Completed higher education of scientists' parents and roles of scientists in higher education. Analysis of the roles of scientists in higher education according to completed higher education of their parents (one or both parents completed the education in higher education school) revealed that here were no the statistically meaningful differences (the non-parametric criterion by Mann-Whitney was applied) (see Table 9).

Table 9

Comparison of scientists' roles in higher education according to completed higher education of their parents

\begin{tabular}{lcccc} 
Role & $\begin{array}{c}\text { Both parents } \\
\text { completed the } \\
\text { higher } \\
\text { education }\end{array}$ & $\begin{array}{c}\text { One of parents } \\
\text { completed the } \\
\text { higher education }\end{array}$ & $\begin{array}{c}\text { Mann } \\
\text { Whitney U }\end{array}$ & $\mathrm{p}$ \\
\hline Critic & 3.84 & 4.11 & 301.5 & 0.321 \\
Advocate & 3.56 & 3.59 & 347 & 0.827 \\
Mentor & 3.16 & 3.38 & 300 & 0.313 \\
Guardian & 3.68 & 3.67 & 348.5 & 0.966 \\
Enabler & 3.33 & 3.30 & 328.5 & 0.699 \\
edge producer & 3.67 & 3.54 & 279.5 & 0.219 \\
demic citizen & 3.73 & 3.60 & 291.5 & 0.306 \\
& 3.74 & 3.62 & 317 & 0.660 \\
\hline
\end{tabular}




\begin{tabular}{ccccc}
\hline $\begin{array}{c}\text { Boundary } \\
\text { transgressor }\end{array}$ & 3.65 & 3.31 & 245 & 0.068 \\
Public intellectual & 3.00 & 2.88 & 3015.5 & 0.434 \\
\hline
\end{tabular}

Though the statistically significant differences were not identified, but some roles, for example, the ambassador, the critic, the advocate, were assessed more positively by scientists one of whose parents were completed the higher education school. The remaining roles were better appreciated by scientists whose both parents were completed the higher education.

Identification of roles by implementing the intellectual leadership among scientists. For each respondent was calculated the mean of responses in association with every block (representing the particular scientist's role). The mean was established as the implicit rate, which showed the average rating for every research participant within the particular scientist's role in higher education. The correlation, which was calculated with the implicit rates, revealed assessment priorities regarding different scientists' roles among respondents (see Table 10).

Table 10

Numerical characteristics regarding scientists' roles that were assigned by the research participants

\begin{tabular}{ccccc} 
Role & $\begin{array}{c}\text { The smallest } \\
\text { value }\end{array}$ & $\begin{array}{c}\text { The biggest } \\
\text { value }\end{array}$ & $\begin{array}{c}\text { Mean } \\
\text { deviation }\end{array}$ \\
\hline Ambassador & 1.00 & 5.00 & 3.826 & 0.878 \\
Critic & 1.06 & 4.54 & 3.502 & 0.469 \\
Advocate & 1.00 & 4.44 & 2.767 & 1.283 \\
Mentor & 1.91 & 4.92 & 3.650 & 0.585 \\
Guardian & 1.33 & 5.00 & 3.313 & 0.730 \\
Enabler & 1.00 & 5.00 & 3.545 & 0.776 \\
Knowledge producer & 2.20 & 5.00 & 3.643 & 0.595 \\
Academic citizen & 2,00 & 5.00 & 3.702 & 0.678 \\
Boundary transgressor & 1.60 & 5.00 & 3.433 & 0.656 \\
Public intellectual & 1.22 & 4.50 & 2.959 & 0.717 \\
\hline
\end{tabular}

The highest mean was associated with the role of the ambassador (3.826), and the lowest mean was related to the role of the advocate (2.767). The role of the scientist as the advocate was assessed from the lowest possible value (from 1.00 to 4.44 ) - the lowest values among all highest values. It is important to note that the highest standard deviation value was also related to the role of the advocate. It showed that opinions of the research participants regarding this role were mostly splited. The smallest differences were revealed regarding assessment of the roles of the mentor and the knowledgde producer. Evaluating the statistically meaningful (significant) differences among assessment values regarding the roles, and applying the ANOVA of repeated calculations were found that differences are statistically significant 
(sphericity: Mauchly`s $\mathrm{W}=0.041 ; \chi^{2}=312.98 ; \mathrm{df}=65 ; \mathrm{p}=0.000$; averages equality: $\mathrm{F}=51.052 ; \mathrm{df}=7.915 ; \mathrm{p}=0.000$ ).

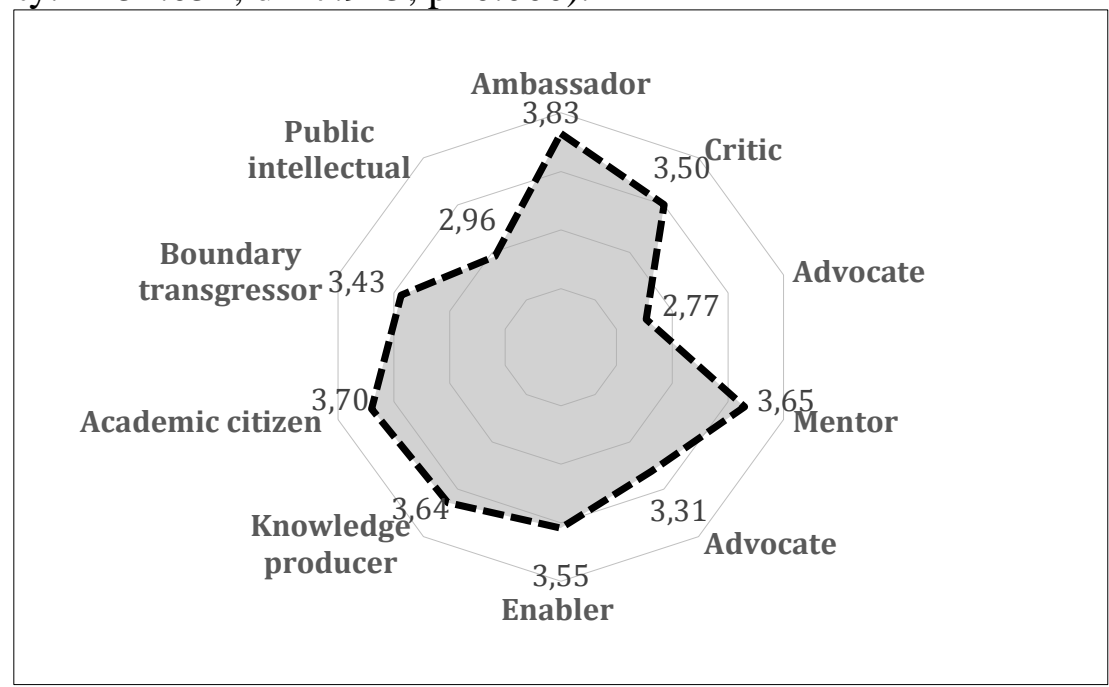

Figure 1. Comparison of means regarding scientists' roles by implementing intellectual leadership in higher education

According to means it could be noted that for respondents mostly meaningful roles are the following (see Figure 1): ambassador and academic citizen. Research participants did not value the roles such as advocate and public intellectual. Analysis of correlations between the separate blocks showed that all the correlations were statistically significant (see Table 11).

Table 11

Correlation between the scientists' roles in higher education

\begin{tabular}{|c|c|c|c|c|c|c|}
\hline Role & Index & Critic & $\begin{array}{c}\text { Advo- } \\
\text { cate }\end{array}$ & Mentor & Guardian & Enabler \\
\hline \multirow{2}{*}{$\begin{array}{l}\text { Ambassa- } \\
\text { dor }\end{array}$} & Correl. coeff. & $.423^{* *}$ & $.275^{* *}$ & $.514^{* * *}$ & $.516^{* *}$ & $.494^{* *}$ \\
\hline & Sig. (2-tailed) & .000 & .002 & .000 & .000 & .000 \\
\hline \multirow{2}{*}{ Critic } & Correl. coeff. & 1.000 & $.588^{* *}$ & $.533^{* *}$ & $.603^{* *}$ & $.499^{* *}$ \\
\hline & Sig. (2-tailed) & & .000 & .000 & .000 & .000 \\
\hline \multirow[t]{2}{*}{ Advocate } & Correl. coeff. & & 1.000 & $.511^{* *}$ & $.475^{* *}$ & $.420^{* * *}$ \\
\hline & Sig. (2-tailed) & & & .000 & .000 & .000 \\
\hline \multirow{2}{*}{ Mentor } & Correl. coeff. & & & 1.000 & $.641^{* *}$ & $.675^{* *}$ \\
\hline & Sig. (2-tailed) & & & & .000 & .000 \\
\hline \multirow[t]{2}{*}{ Guardian } & Correl. coeff. & & & & 1.000 & $.637^{* * *}$ \\
\hline & Sig. (2-tailed) & & & & &, 000 \\
\hline Role & Index & $\begin{array}{l}\text { Knowledge } \\
\text { producer }\end{array}$ & $\begin{array}{l}\text { Acade- } \\
\text { mic ci- } \\
\text { tizen }\end{array}$ & \multicolumn{2}{|c|}{$\begin{array}{l}\text { Boundary } \\
\text { transgre-ssor }\end{array}$} & $\begin{array}{c}\text { Public } \\
\text { intellectual }\end{array}$ \\
\hline \multirow[t]{2}{*}{ Ambassador } & Correl. coeff. & $.496^{* *}$ & 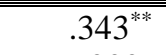 & \multicolumn{2}{|c|}{$.417^{* *}$} & $.240^{*}$ \\
\hline & Sig. (2-tailed) & .000 & .000 & \multirow{2}{*}{\multicolumn{2}{|c|}{$\begin{array}{l}.000 \\
484^{* *}\end{array}$}} & .014 \\
\hline Critic & Correl. coeff. & $.545^{* *}$ & $.556^{* *}$ & & & $.508^{* *}$ \\
\hline
\end{tabular}




\begin{tabular}{clcccc}
\hline \multirow{3}{*}{ Advocate } & Sig. (2-tailed) & .000 & .000 & .000 & .000 \\
& Correl. coeff. & $.417^{* * *}$ & $.435^{* *}$ & $.311^{* *}$ & $.343^{* *}$ \\
& Sig. (2-tailed) & .000 & .000 & .001 & .000 \\
& Correl. coeff. & $.579^{* *}$ & $.484^{* *}$ & $.511^{* *}$ & $.316^{* *}$ \\
Mentor & Sig. (2-tailed) & .000 & .000 & .000 & .001 \\
& Correl. coeff. & $.726^{* *}$ & $.427^{* *}$ & $.520^{* *}$ & $.463^{* *}$ \\
Guardian & Sig. (2-tailed) & .000 & .000 & .000 & .000 \\
& Correl. coeff. & $.728^{* *}$ & $.624^{* *}$ & $.733^{* *}$ & $.478^{* *}$ \\
Enabler & Sig. (2-tailed) & .000 & .000 & .000 & .000 \\
Knowledge & Correl. coeff. & 1.000 & $.579^{* *}$ & $.660^{* *}$ & $.376^{* *}$ \\
producer & Sig. (2-tailed) & & .000 & .000 & .000 \\
Academic & Correl. coeff. & & 1.000 & $.470^{* *}$ & $.591^{* *}$ \\
citizen & Sig. (2-tailed) & & & .000 & .000 \\
Boundary & Correl. coeff. & & & 1.000 & $.408^{* *}$ \\
transgressor & Sig. (2-tailed) & & & .000 \\
\hline
\end{tabular}

Strongest correlatons, which exceed 0.7, were identified between the roles of the guardian and the knowledgde producer $(\mathrm{r}=0.726, \mathrm{p}=0.000)$, the enabler and the knowledge producer $(\mathrm{r}=0.728, \mathrm{p}=0.000)$, and the enabler and the boundary transgressor $(\mathrm{r}=0.733, \mathrm{p}=0.000)$ (see Table 10$)$.

\section{Discussion}

Findings showed that for researchers representing social sciences the roles of the advocate and the critic were more worth than for researchers from other research areas. These results could be seen through social researchers' identification of themselves with the interests of their colleagues within the higher education school. Social researchers in their scientific studies mostly deal with subjective practices, raise questions regarding social, political, moral, educational, psychological, justice, ethical and other values, they are focused on critical reflections in variety of levels, for example, individual, organizational, societal. Also in most cases in their studies they apply the context-specific and situation-sensitive research methods in order to see the phenomenon from inside. The objective research methods in social researcher practices are not a priority (Gay \& Airasian, 2003). Social researchers in their scientific activities rely on projected ideals of collegiality in their relationships with higher education school colleagues (Greenbank, 2003). Scientists from other research areas rely mostly on their personal / individual authority and competencies, and the collegiality here is seen as a weakness within the scientific competence framework and / or research area (Smyth \& Nosek, 2015). Also scientists (especially from humanities, technical, natural sciences) react very sensitively regarding critic by seeing it as personal incompetence (Uslu \& Arslan, 2015). 
Findings revealed that the lowest assessments were related to the role of the mentor nevertheless of the scientist's research area. It seems that this issue is more national than international. In Lithuania within the higher education here is no mentorship system, which could be seen as systemic work and which is treated as important activity in higher education school. Mentorship of scientists in Lithuania is still seen as "normal", additional work, which is perceived and performed by a scientist "for granted" (Monkeviciene $\&$ Rauckiene, 2010). Then scientists treat this work as a void because it takes a lot of their own time and is not respected within the higher education arena. The moral benefit is not worth for scientists because they are overloaded with their direct activities, and the mentorship is seen as additional and time consuming work (Monkeviciene \& Rauckiene, 2009).

Findings represented the empirical fact that more experienced scientists in higher education area more value the roles of the academic citizen and the public intellectual. This result may be observed through the attitude that less experienced colleagues do not worth these roles as intellectual leaders in higher education schools. Working in higher education school teaches the scientists many valuable lessons, even if their job isn't challenging every day (Life, 2013).

Results of the research highlighted that the roles such as the ambassador, the critic, the advocate were assessed more positively by scientists one of whose parents were completed the higher education school. These findings showed that scientists who were raised in fimilies in which their parents completed the education in higher education schools (universities), they probably got the perceptions, understandings about the mission and the value of higher education in individual life and development, and in society locally, nationally and / or internationally (Albert et al., 2000; Blackmore \& Blackwell, 2006; Harpur, 2010). This value is related to the understanding that higher education is focused on the mission to add to the understanding of, and hence the flourishing of, an integrated social, institutional, cultural and economic life. It contributes both to individual fulfilment and the collective good. Higher education is also an end in itself, through its pursuit of knowledge, understanding and meaning (Macfarlane, 2012).

\section{Conclusion}

Intellectual leadership of a scientist in higher education is not about the labor skills and qualifications. It is about everyday learning from acting and reflecting. Even then when intellectual leadership of the scientist is seen through particular roles in higher education it does not mean that these roles are in position of status quo. The three core messages from this pilot study are the following: i) scientists from social research area see more complex their 
role performance in higher education school; ii) academic work experience of the scientist in higher education and iii) the completed higher education of scientist's parents matter in his / her intellectual leadership. Scientists rebuild and enhance their capabilities at the personal, interpersonal and institutional levels in order to address the challenges and capabilities in higher education. It requires from them to learn from experience, to become more open to their role performance, to find out the potential of overlaps between their roles and to transfer the values of higher education through generations in higher education school and in society. Scientists as higher education providers, the value keepers / guardians, representatives of higher education require a shared understanding of roles and values within intellectual leadership, which they implement in variety of levels within the higher education arena. Probably, it is the important step to learn to be open to learn new opportunities and challenges within higher education space.

\section{Acknowledgements}

Financial support provided by the Research Council of Lithuania for the research and English language proof-reading is gratefully acknowledged (Project Reg. No. MIP-15268, Agreement No. 026/2015).

The author of the article expresses appreciation to dr. A. Rutkiene, who helped to manage the statistical aspects, and to V. Jurgile, who helped to manage technically the data collection process. The author is grateful to dr. E. Dailidiene for editing the English language.

\section{References:}

Albert, S., Ashforth, B. E., \& Dutton, J. E. (2000). Organizational identity and identification: charting new waters and building new bridges. Academy of Management Review, 25(1), 13-17.

Austin, J. H. (1998). Zen and the Brain: Toward an Understanding of Meditation and Consciousness. Cambridge, MA: MIT Press.

Blackmore, P., \& Blackwell, R. (2006). Strategic leadership in academic development. Studies in Higher Education, 31(3), 373-387.

Brinley, F. (2012). Surviving to Thriving: Advancing the Institutional Mission. Journal of Library Administration, 52(1), 94-107.

Calarco, M., \& Atterton, P. (2009). Animal Philosophy: Essential Readings in Continental Thought. New York, NY: Continuum.

Carmeli, A., \& Halevi, M. Y. (2009). How top management team behavioral integration and behavioral complexity enable organizational ambidexterity: The moderating role of contextual ambidexterity. Research Policy, 20(2), 207218.

Chen, J. Q. (2003). Intelligence: Multiple intelligences. In J. Guthrie (ed.). Encyclopedia of Education (pp. 1198-1201). New York, NY: Macmillan. 
Clancy, T., Stiner, C., \& Koltz, T. (2002). Shadow Warriors: Inside the Special Forces. New York, NY: Putnam.

Connelly, L. M. (2008). Pilot studies. Medsurg Nursing, 17(6), 411-412.

Dealtry, R. (2001). Managing intellectual leadership in corporate value. Journal of Workplace Learning, 13(3), 119-124.

Fowler, F. J. (2014). Survey Research Methods. Thousand Oaks: Sage Publications.

Gay, L. R., \& Airasian, P. (2003). Educational Research: Competencies for Analysis and Applications. Upper Saddle River, NJ: Pearson Education.

Gornitzka, A., Kyvik, S., \& Stensaker, B. (2005). Implementation analysis in higher education. In Reform and Change in Higher Education. Peter Maassen (ed.). (pp. 35-56). Dordrecht, The Netherlands: Springer.

Greebank, P. (2003).The role of values in educational research: the case for reflexivity. British Educational Research Journal, 29(6), 791-801.

Harpur, J. (2010). Innovation, Profit and the Common Good in Higher Education. The Netherlands: Springer.

Hennink, M., Hutter, I., \& Bailey, A. (2011). Qualitative Research Methods. London: Sage Publications.

Hertzog, M.A. (2008). Considerations in determining sample size for pilot studies. Research in Nursing \& Health, 31,180-191.

Jain, S., George, G., \& Maltarich, M. (2009). Academics or entrepreneurs? Investigating role identity modification of university scientists involved in commercialization activity. Research Policy, 38(6), 922-935.

Julious, S. A. (2005). Sample size of 12 per group rule of thumb for a pilot study. Pharmaceutical Statistics, 4, 287-291.

Life, B. (2013). Why Gaining Work Experience is More Important than Your Education? Available at: http://www.huffingtonpost.com/brazen-life/whygaining-work-experien_b_3750261.html (Accessed on 24/07/2016).

Macfarlane, B. (2011). Professors as intellectual leaders: Formation, identity and role. Studies in Higher Education, 36(1), 57-73.

Macfarlane, B. (2012). Intellectual leadership in Higher Education: Renewing the Role of the University Professor. London: Routledge.

Monkeviciene, O., \& Rauckiene, A. (2009). The Development Mentoring System in Lithuania: Theoretical and Practical Dimensions. Available at: http://www.eera-ecer.de/ecer-programmes/conference/2/contribution/2478/ (Accessed on 24/07/2016).

Monkeviciene, O., \& Rauckiene, A. (2010). Improvement of teacher training quality in Lithuanian higher educational institutions: establishment of mentorship institution. Teacher Education, 14(1), 12-25.

Review on Situation of Research and Study in Lithuania (2016). Vilnius: The Center for Observation and Analysis. In Lithuanian language. Available at: 
http://mosta.lt/images/leidiniai/Lietuvos_mokslo_ir_studiju_bukle_2016.pdf (Accessed on 23/07/2016).

Rowley, D. J., \& Sherman, H. (2003). The special challenges of academic leadership. Management Decision, 41(10), 1058-1063.

Roy, A., Giovannini, F., Satterthwaite, D., \& Chaturvedi, B. (2008). Global Norms and Planning Forms: The Millennium Development Goals Towards an Intellectual Leadership: Rediscovering the Role of the United Nations in the 21st Century. The Central Role of Local Organizations in Meeting the Millennium Development Goals (MDGs). The Story of Chintan. Planning Theory \& Practice, 9(2), 251-274.

Smyth, F. L., \& Nosek, B. A. (2015). On the gender-science stereotypes held by scientists: explicit accord with gender-ratios, implicit accord with scientific identity. Frontiers in Psychology, 6, 415. Available at: http://www.ncbi.nlm.nih.gov/pmc/articles/PMC4410517/ (Accessed on 24/07/2016).

Stevenson, H. (2012). Teacher leadership as intellectual leadership: creating spaces for alternative voices in the English school system. Professional Development in Education, 38(2), 345-360.

Tavakol M., \& Dennick, R. (2011). Making sense of Cronbach's Alpha. International Journal of Medical Education, 2, 53-55.

Tseng, H.-CH., Tung, H.-L., \& Duan, Ch.-H. (2010). Mapping the intellectual structure of modern leadership studies. Leadership \& Organization Development Journal, 31(1), 57-70.

Uslu, B., \& Arslan, H. (2015). Faculty's academic intellectual leadership: predictive relations with several organizatinal characteristics of universities. Journal of Higher Education and Science, 5(2), 125-135.

van Teijlingen, E., \& Hundley, V. (2001). The importance of pilot studies. Social Research Update, 35, 1-4.

Yielder, J., \& Codling, A. (2004). Management and Leadership in the Contemporary University. Journal of Higher Education Policy and Management, 26(3), 315-328.

Zou, K. H., Tuncali, K., \& Silverman, S. G. (2003). Correlation and simple linear regression. Radiology, 227(3), 617-622.

Zydziunaite V. (2007). Research Design: Structure and Strategies. Kaunas: Technologija. [In Lithuanian language].

Zydziunaite, V., Butautaite, V., Rutkiene, A., \& Tandzegolskiene, I. (2015a). Multilayered considerations on the concept of "leadership": conceptual views in psychology, management and education. European Scientific Journal, 11(25), 17-28.

Zydziunaite, V., Tandzegolskiene, I., \& Rutkiene, A. (2015b). Considerations on a scientist's academic mission and roles in a higher education school. Acta Technologica Dubnicae, 5(2), 51-68. 